ACTA UNIVERSITATIS CAROLINAE,

CHARLES UNIVERSITY IN PRAGUE,

FACULTY OF PHYSICAL EDUCATION AND SPORT,

DEPARTMENT OF PEDAGOGY, PSYCHOLOGY

AND DIDACTICS OF PHYSICAL EDUCATION AND SPORT

\title{
ARE OLYMPIANS REAL IDOLS OF YOUNG PEOPLE FOR THEIR MOTIVATION AND PARTICIPATION IN SPORT?
}

\author{
ANTONÍN RYCHTECKÝ
}

\section{SUMMARY}

The aim of this study was to determine: "if Olympic champions are real models and idols for today's young people" and whether they would wish or not to become Olympic champions, and which reasons they associate with their positive or negative answers. 440, 12 and 15 year old respondents participated in surveys carried out in the year 1998 (12 and 15 year old respondents only) and consequently in the period 2010-2011 in which 1274 boys and 1090 girls, 12-19 years, old were respondents in this project. The quota samples were used in the selection of respondents in Prague' and the Central region in the Czech Republic. The parts of the "Olympic Questionnaire", created and verified in the 1998 survey were focused on the analysis of the respondents' answers. The open answers of the respondents were subsequently divided into several general and common categories. The desire to become an Olympic Champion was felt more intensely in respondents of the surveys carried out in the year 1998 than in the project carried out in period 2010-2011. Young people more involved in sports express their wishes to become Olympic winners significantly clearer than those who practice sports seldom or not at all. Over 16 year old respondents are more aware of the difficulties associated with the process of becoming Olympic champions than 12-14 year old pubescent. The evaluation of the differences and identical opinions between the respondents' answers in the observed groups were made by the MANOVA and t-tests for independent samples. The hypothesis about the importance of sports models and idols in current youth was confirmed. The role of Olympic champions is very important; namely in the internalization of the Olympic values in the process of the Olympic education of youth; both at schools and out of schools. Olympians should be aware of the fact that even their behavior which is not related to sport events is noticed by young people. The Olympians should be informed about their influence on young generations. Mass-media play a very important role in their mediation. For these reasons, the collaboration between the Club of Czech Olympians and the Olympic Academy should be innovated.

Keywords: Olympic education, elite sport, identification of model and idols, desire to be an Olympic winner 


\section{INTRODUCTION}

Models and idols in pedagogical and kinanthropological researches are frequently studied and monitored. They belong to the basic factors of the socialization process. They are particularly important in the education of youth, in shaping of their value orientation, belief, attitudes, etc. Some of them are stable and consolidated in the course of socialization, and individuals can identify with them. Other models and idols are in the ontogenesis gradually abandoned and lose their former significance.

Models and idols are functional and operate in the different spheres of human activities: in the arts, sports, science, commerce, etc., and form part of the contemporary world. The terminology and content of the models and idols are differing from each other. In particular, they are differing in the depth of emotional experiencing.

Models are those persons whom other individuals imitate. In contrast, idols are admired, loved and honored by the others (Biskup \& Pfister, 1999; Scheepers, 2013). The idol, unlike the model has a significantly greater depth and level of influence on society, social groups or on individuals. The individual, who identifies himself/herself with the idol or model, increases his/her value by imitating people who have a high prestige, performance, values, opinions, beliefs, etc.

\section{The role of models and idols in ontogenesis}

Young people are under the informal influences of parents, friends, cultural production, athletic performance, mass-media presentations, etc. as well as formal an intentional stimuli at schools, sports clubs, etc. and through the own activity create their personal celebrities, models, idols, etc., But what is most important, in order that models and idols reflect such values they be should be indoctrinated to young people, especially in the early stages of ontogenesis. Value orientation and attitudes should be previously created. Without the models and idols the development of an individual may be somewhat limited (Bromnick \& Swallow, 1999). It should be highlighted that the transition from childhood to adolescence is not only a biologically conditioned process, but it also implies a change in the attitudes of subjects towards their models or idols.

Children, more often than the other age groups in society, identify them through sportsmen, stars, idols and heroes. Persons who are admired for their qualities and achievements are considered to be Olympic heroes (Biskup \& Pfister, 1999; Carr \& Weigand, 2002; Lines, 2001; Vescia, Wilde \& Crosswhite, 2005).

On the other hand Scheepers (2013) pointed out that it would be wrong to form a model only by his/her success and not according to the values that he or she represents. The position and successful individuals are often considered as the reference standards in the assessment of the overall model or idol. The tendency to overestimate the status and popularity of models and idols, can suppress values such as honesty, trust, compassion, truth, responsibility, kindness, etc., which should be included in the values of an effective and satisfied society (Andrews \& Jackson, 2001).

The perception of models and idols associated with the gender of individuals. For example, Bishop \& Pfister (1999) found that athletes of both genders in the role of models and idols are significantly less assessed by women, while Ewens and Lashuk 
(1989) found that male athletes are significantly more selected as a models than female athletes. The girls found their source of identification rather in models presented on television screens and pages of magazines than in other areas, including the sports environment (Lines, 2001). The importance and impact of models and idols are amplified, especially through media coverage. This may concern all or certain social groups and individuals.

Models and idols may not always have a positive effect. They may also present negative attitudes, values and behavioral patterns. Motivation of young people to participate in sport, is often associated to their sports models, which can sometimes be more effective than the emotional pattern of acceptance by parents or friends and optimizes their interest in the practice of sports. Athletes may play a negative role of models because of an improper or illegal behavior, which however, despite their inadequacies are often presented in mass-media. The media play an important role in how the sport and sports personalities in particular influence children and youth (Andrews and Jackson, 2001). Of course there are many excellent sports personalities who the positive behaviors directly personify (Scheepers, 2013; Femiak \& Rymarczyk, 2010). Idols and models which symbolize and reinforce the standards and ideals in society or in specific groups are predominately considered as desirable (Biskup \& Pfister, 1999).

\section{Athletes, Olympic champions - as the models for youth}

On the occasion of the 150 anniversary of the birth of the founder of modern Olympism Pierre de Coubertin, it is good to remember some of his thoughts, ideals and his efforts in his mission to create a modern and global Olympic Movement. Pierre de Coubertin viewed the athletes - Olympians as the ambassadors of peace and disseminators of the Olympic ideals. Indeed, the athletes were and are important models and idols that young people and not only they ones, who imitate, identify and admire them. For example John DeFrancisco, state senator in New York, Syracuse, on the background of the OG 2012 made two remarks: a) In OG there are more inspiring things than their results. It is wonderful that there still are those who are willing to spend countless hours to become successful. b) It is truly refreshing to see and hear the interviews of the successful Olympians. They are reflective, humble, thankful and articulate, in contrast to many of our current sports and entertainment idols who all too often simply try to push the envelope for notoriety, not caring about the effect they may have on our youth. He closes these comments with the following challenge: "we desperately need role models and thankfully, we now have them".

\section{Aims of the study}

The aims of the current empirical and comparative study were to identify:

- Who are the models and idols among Czech youth?

- Are the Olympic champions the real models, idols and heroes, with whom today's young people can identify?

- What changes in the identification of the sport models and idols of youth, were noticed in the surveys carried out in the period between 1998 and 2011 ? 
- What are the most frequent motives which young people associate with their positive and with their negative responses to the question: "Would you like to become an Olympic champion or not?"

\section{Method and respondents}

The default research method was an Olympic questionnaire, standardized in the framework of the European project: "Physical Fitness, Sporting Lifestyle and Olympic Ideals: Cross-Cultural Studies on Youth Sport in Europe" carried out in the period 1996-1998 (Telama, Naul, Nupponen, Rychtecký \& Vuole, 2002).

The first survey was carried out in the year 1998 and 440 boys and girls, 12 and 15 years old participated in it.

In the second survey, carried out in the years 2010 and 2011, 1274 boys and 1090 girls in the age 12-18 years, selected by the quota samples were respondents.

In both studies the students were asked to reply to the questions and fulfill the tasks:

- Who, among the Olympians are most admired by the respondents and which are the main reasons for it?

- Would you want to be an Olympic champion or not?

- To record the reasons or motives why do you want to become, or don't want to become an Olympic champion.

- Open answers of respondents were subsequently divided into several general and common categories.

\section{RESULTS}

\section{The models and idols in Czech youth}

Interesting results have been found in the survey of the Sofres-Factum Agency carried out in 2002 in the Czech Republic. Young 18-25 year old people were asked: "Who is a model or idols for them?" The most frequent responses to this question were - the athletes. Olympic champions especially reached the highest position in this survey (see Figure 1)

It is a positive fact that the athletes, particularly Olympic champions belong to the most frequent models and idols among youth. On the other hand, the findings that $34 \%$ of young people do not, or cannot determine their models or idols and identify themselves with them are not too positive. These individuals and groups of youth are not usually involved in some socially desirable leisure-time activities and therefore cannot satisfy their needs and cannot find their models or idols. In response to the question of what actually the models and idols are in general, the answer should be that models of virtue and success were always an integral part in childhood. Their imitation and identification should be one of the basic methods not only in cultural, but also in Olympic education.

According to Čáp (2010) it is the ancient civilization pattern in which some heroes or heroines may affect the youth just by the mere fact of their existence. 


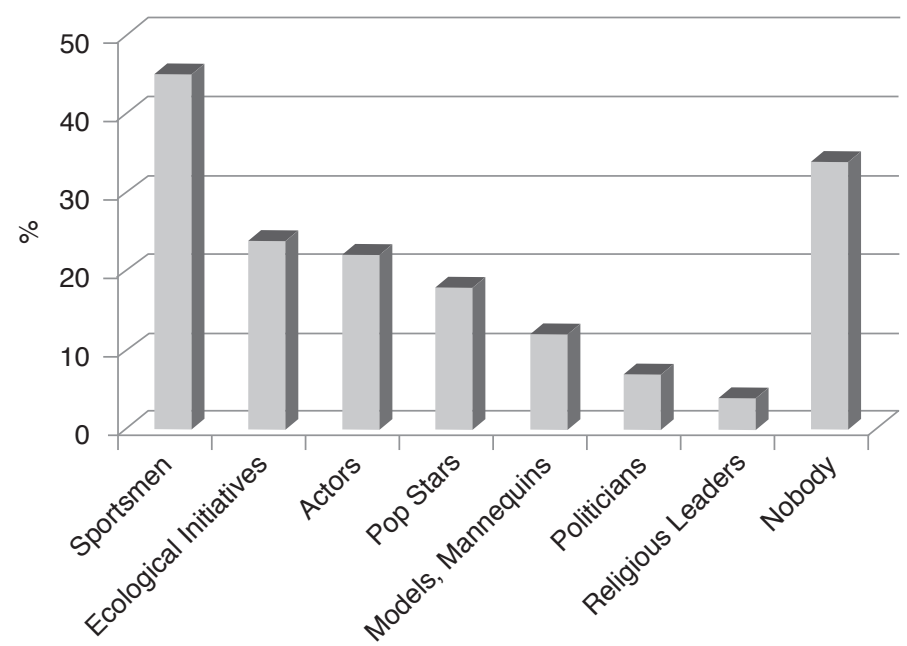

Figure 1. The models and idols in Czech youth (Sofres-factum Agency, 2002)

\section{Sport Models and Idols in Czech youth}

Assessments of the Olympic Champions as models and idols were carried as an integral part in the two above mentioned survey, carried out in the years 1998 and 2011.

In these surveys the respondents were asked to list their three favorite Olympic champions and shortly explain the reasons for choosing of them. The respondents should answer the question: "Which male and female Olympic champions do you admire?"

The results in both studies showed that boys and girls previously admired the national sport models, idols and heroes of high repute. The respondents very seldom selected the so-called "megastars", internationally famous persons (Lewis, Agassi, etc.) who were well known in mass media, namely in TV reports of the Olympic Games.

The respondents in 1998 selected the first three of admired sport males: Železný, Zátopek, Změlík. In the 2011 study the order in the answers was as follows: Šebrle, Železný and the Czech hockey team. $49.7 \%$ and $46.9 \%$ of the respondents in 1998 , respectively in 2011 did not replay or were not able answer this question. With respect to the international female "megastars", they were selected also in summer and winter sports (Bonaly, Ottey, Sally Gunnel etc).

In Czech Olympians females, in the 1998 project the order was: Č́slavská, Ottey and Kratochvílová. In the second study in 2011 the sport females were selected in the following order: Neumanová, Sáblíkova and Hilgertová. $65 \%$ and $52.8 \%$ of respondents did not fulfill this task.

It is a remarkable and nice finding that young boys and girls were and are familiar with former Olympic champions. For example Zátopek and Časlavská are still popular. Časlavská is still involved in sport and helps in the promotion of the Olympic Movement. 
With respect to the reasons why the respondents specified their choice of concrete Olympic champions some common and some specific motives were ascertained.

In the selection of the indicators: "Good Athlete", "Top Performer" and "Fair Player" dominated. However, the students also had a few, very personal reasons for their choices such as "nice and attractive person", "I like his sports" or "I like his appearance in public life", which was more likely to be connected with the athlete's appearance reported by the mass media (TV, newspaper).

A few and slight differences were apparent in selecting male or female Olympic champions. The most important reasons given for selecting Olympic champions in 1998 were: "Good Athlete", "Skillful/Fast" and "Fair Player". In the 2011 project in both genders the order: was as follows "Good athlete", "Personal reasons" and "National pride" which were found as coincident with the respective reasons for selecting male and female Olympic champions. Fewer students reported also the "National Pride". $2.7 \%$ of girls and $14 \%$ of boys reported it as an important factor in their choices.

\section{Self-assessment of becoming an Olympic Champions or not}

The students were asked whether it was important for them to become an Olympic champion. The question, to which the respondents should to reply, was: "Would you like to become an Olympic champion?" In addition, the students were asked to record reasons either for wanting to become, or not wanting to become an Olympic champion. According to the free responses of the examined persons have been according to its frequency, content compliance, etc., were generalized into several categories. Differences in responses, in terms of gender, age, participation in sports, and membership in clubs and participation in sports competitions were substantively and statistically processed and evaluated.

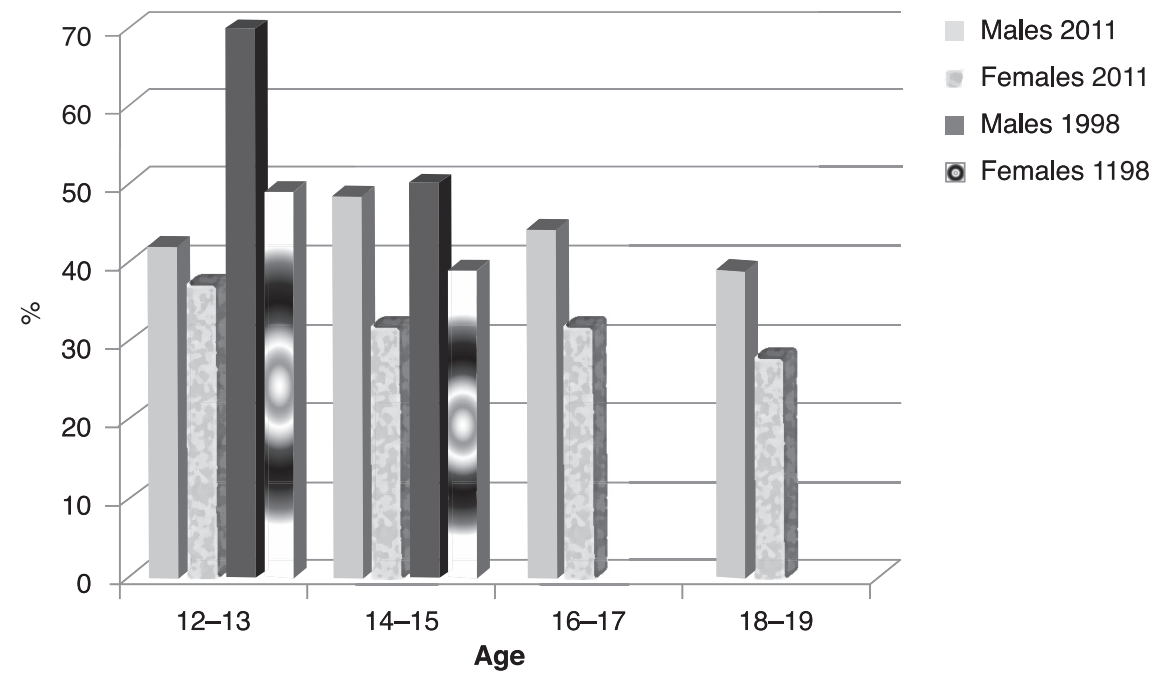

Figure 2. Would you like to become an Olympic champion? The affirmative responses only (2011; in \%). 
Participation of respondents in physical and sports activities was administered by the questionnaire COMPASS (Mussino, 1997; Rosi-Mori, 1998; Rychtecký, 2006), which combines three essential criteria: organization in sport clubs, participation in competitions and frequency of participation in sport and physical activities in the annual overview. It sets out eight basic categories from 1: competitive, organized, intense activity to 8: no physical activity and sports.

Data about the self-assessment of the importance of becoming or not becoming an Olympic champion give further explanations regarding assessments of the other items about the Olympic Idols and some lifestyle criteria about the intensity of physical activities, participation in competitions and reasons for exercising and their application in the concepts of Olympic education.

The results in Figure 2 document compliance of data from the research in 2011 with the data identified in the list of Sofres-Factum Agency (2002) and a survey of 1998. They show that the most significant models and idols for $40-50 \%$ of boys and $32 \%$ of girls aged 14-15 years are the athletes. Approximately the same number of respondents, according to our surveys of 1998 and 2011, would like to become Olympic champions (Telama, Naul, Nupponen, Rychtecký \& Vuole, 2002). The significant differences between the data in those projects were identified in the 1998 and 2011 studies by t-test for independent samples in groups of twelve year old respondents only. Twelve year old boys in

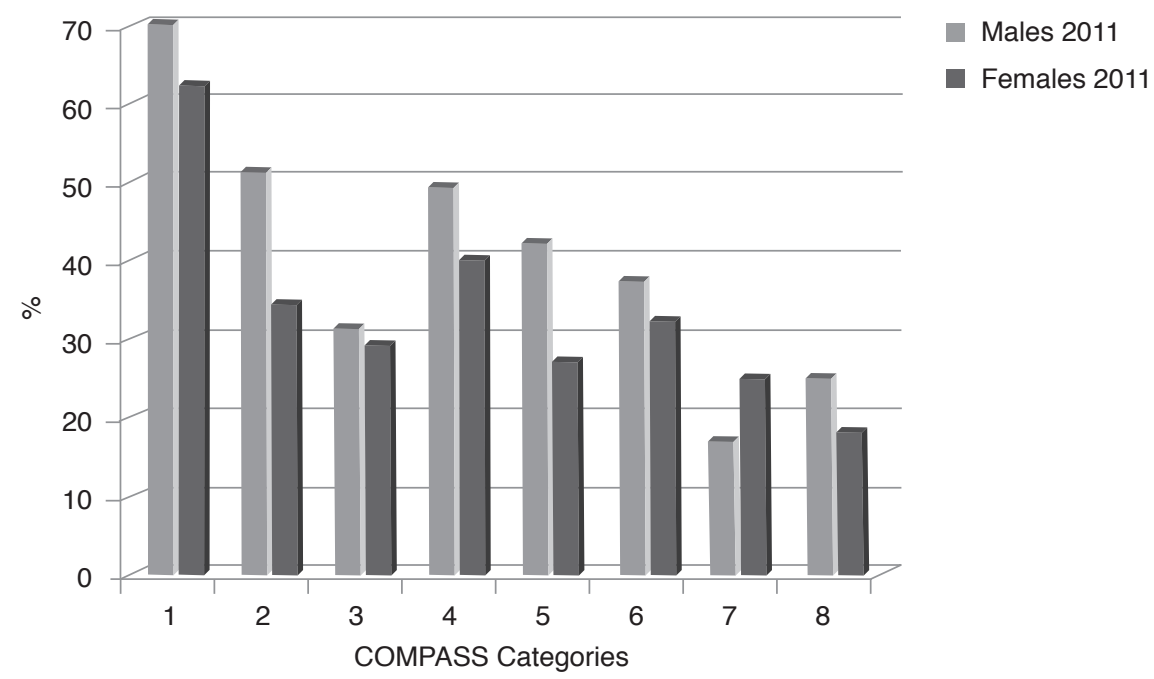

Figure 3. The relationship between the frequency of physical and sports activities and preferences in wish to become Olympic champions (study in 2011; \%)

Legend: 1. Competitive, organized, intensive. Annual frequency (AF) more than 120, competitions in one sport at least, member of sports club. 2. Intensive, competitive and/or organized. AF more than 120, competitions at least in one sport or membership at a sports club. 3. Intensive. AF more than 120 , no competition in sports, no membership at a sports club. 4. Regular, competitive and/or organized. AF $60-120$, competitions in one sport at least, member of sports club. 5. Regular, recreational. AF $60-120$, no competitions in sports, no membership in sport club. 6. Irregular. AF 12-60. 7. Occasional. AF 1-12. 8. No participation in sports and physical activities. 
a 1998 study declared a higher frequency in the desire to become an Olympic champion $(\mathrm{t}=4.456, \mathrm{p} \leq 0.000)$ than their counterparts in 2011 study.

Differences between the boys and the girls in the 2011 study documented a higher wish in boys to become Olympic champions. That is, depending on the age of the tested persons it was always higher than in the girls. As the age of the respondents increases, the differences between the age groups increase as well. Most notably it was observed at the age group 14-15 years. In this period, the affirmative declaration of respondents' wish to become Olympic champions attained its peak. In girls a downward trend can be observed in all age ranges, completely coming down and decreases about $10 \%$. For boys, the peak is in 14-15 year old respondents and also decreases to $10 \%$. The differences between the average values of affirmative answers were in addition to the age group 12-13 years statistically and substantively significant (ANOVA, $\mathrm{F}=33.648, \mathrm{p} \leq 0.000$ ).

\section{Association between the participation in physical activity and sports competitions, membership in a sports club and desire to become an Olympic champion}

The results in Figure 3 confirmed the assumption that active and organized sporting boys and girls, more clearly than recreational, not organized, lower sporting, or no sporting respondents would like to become Olympic champions in a statistically significant level.

\section{Reasons why the respondents wish to become Olympic champions}

Open answers of respondents', as it was previously mentioned, were according to the identical contents or related characters divided into eight categories in the case of an affirmative answer to the question of whether they would like to become Olympic

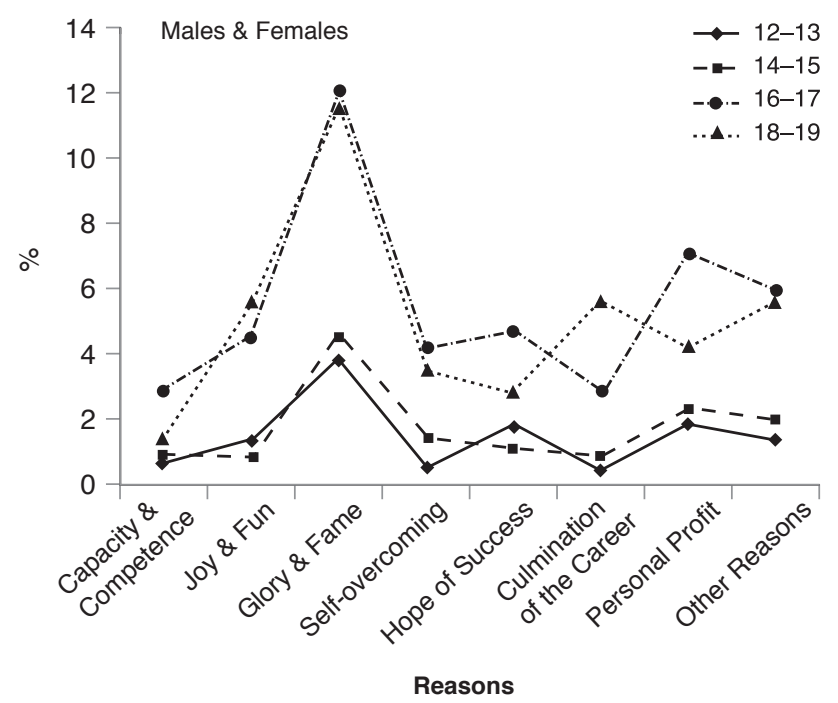

Figure 4. Reasons why the respondents want to become Olympic champions (2011) 
champions?; and to seven categories in the case of negative answer to this question. This approach allows compare the differences between the respondents which correspond to the age, gender and participation in sport of the examined individuals.

Significant consensus in preferences depending on the age of respondents is presented in Figure 4. The age of respondents is a more important factor than gender in the selection of answers why the respondents want to become Olympic champions. With the increasing age of respondents the preferences of some reasons also increase. These findings can be explained by the fact that increases in age autonomy and independence and decreases in the need for someone to look up to. At the same time, however, it may be said that the increasing demands of individuals and problems in finding personalities with whom he/she would like to identify. Older young people are more focused on lifestyles or young people's movements. For example it would be a certain type of music and its collective listening.

The selected reasons, for example: "glory and fame", "personal profit", "joy and fun", "hope for success" or "culmination of the career," "self-overcoming" documented this trend. The profile of these motives is in older respondents aged 16-19 years more dynamic than in younger individuals and stress rather hedonistic characters and not so much the focus on the development of efforts and overcoming obstacles. Themes like "glory and fame", "joy and fun" as the hedonistic categories were identified as the most attractive reasons why respondents would like to become Olympic champions. In contrast, in younger students aged 12-15 years there are differences in preferences of selected reasons which are insignificant with exception "glory and fame". The "Joy and Fun" category is associated with training and participation in competitions, and also with other aspects of lifestyle and sports career of their admired athletes. Statistical evaluation of the difference in averages confirmed significant differences between the respondents' age differences among the age groups in the motive: to become an Olympic champion (MANOVA, $\mathrm{F}=33.648, \mathrm{p} \leq 0.000$ in age and reasons as an independent variables).

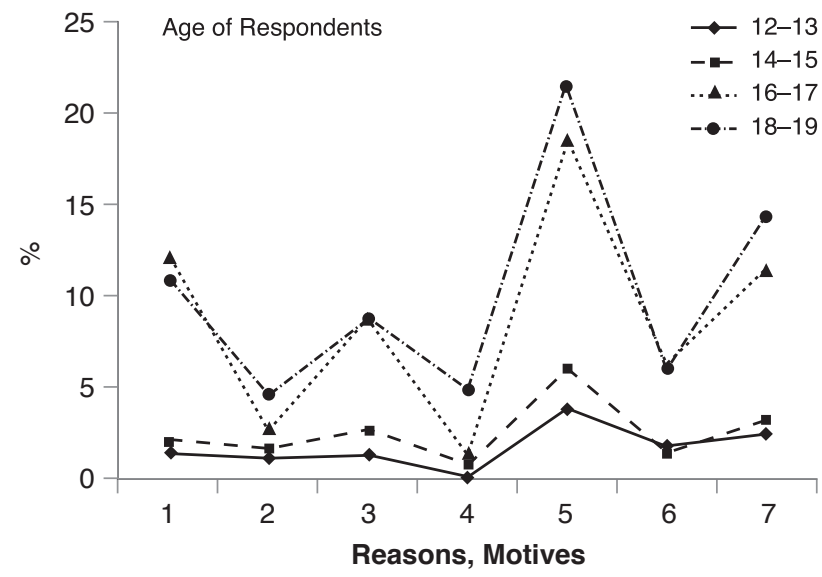

Figure 5. Reasons why respondents don't' want to become Olympic champions Legend: 1 . Too much effort; 2 . Capacity and competences; 3 . The consequences of fame and glory; 4. Fear of failure. 5. Focus on other activities; 6 . I do not like sport; 7. Other reasons. 


\section{Reasons why the respondents not to become an Olympic champion}

The results, in the case of negative answers why the respondents don't want to become Olympic champions are presented in Figure 5. As in the previous case a significant relationship between the age of the respondents and the growing preference were revealed in some reasons. "Another orientation than to sport", "Consequences of fame and glory", "Underdeveloped skills" (capacity and competences) were the main reasons why the respondents do not want to become Olympic champions. Older respondents (16-19 year old) in a greater extent than younger individuals (12-15 years) understand and are aware of the fact that the wish to become an Olympic champion is associated with a high mobilization of voluntary effort, masterfully mastered skills, supply mental and physical forces and low levels of fear of eventual failure.

\section{CONCLUSION}

The role of Olympic champions is very important; namely in the internalization of the Olympic values, in the process of the Olympic education of youth.

The assumption about the importance of sports models and idols in the current conception of Olympic education in youth was confirmed in our studies. Sport models and idols belong to those who are frequently selected as the role of important models and idols in youth. Sport models and idols also play an important role in the personal development of young people. Especially during the pubescence and adolescence the preference of sport idols is very important and has positive impact especially for these target groups.

On the other hand Olympians should be aware of the fact that their behavior which is not related to the sport events is noticed and assessed by young people. The Olympians should be informed about how they influence on young generations. Mass-media can play a very important role in their correct presentation (mediation).

To support of sport brings a double benefit. The first one gives an opportunity to selfrealization in competitive sport, especially in gifted person. The second benefit offered to youth an opportunity in order to select a sport environment with real models and idols, which young people may imitate and identify themselves with. The promotion of top sport contributes and helps to the development of Olympic and sport movements as well.

We assume that sport models and idols may play an important role in encouraging youth participation in sport as a part of the motivation process, in the enhancement of their own self-identification. For sporting individuals they may play a positive role in their identification, namely in grow of their own sports performance.

With respect to the reasons which young people associate with their desire to become or not an Olympic champion, in our investigations it was found that the age of young people more significantly than their gender influences the choice of the values which youngsters attribute to them.

Older respondents (16-19 year old) in a greater extent than younger individuals (12-15 years) understand and are aware of the fact that the desire to become an Olympic champion is associated with a high mobilization of voluntary effort, masterfully mastered skills, supply mental and physical forces and low levels of fear of eventual failure. We 
therefore suggest that sports models and idols should really encourage young people to take part in physical activities and positively influence their personal development.

\title{
ACKNKOWLEDGEMENTS
}

This study was supported by VZ MSMT 0021620864 and PRVOUK 39.

\section{REFERENCES}

ANDREWS, D. L., JACKSON, S. J. (2001). Sports Stars: The Cultural Politics of Sporting Celebrity. London: Routledge.

BISKUP, C., PFISTER, G. (1999). I Would Like to be Like Her/Him: Are Athletes Role-Models for Boys and Girls? European Physical Education Review, 5(3): 199-218

BROMNICK, R. D., SWALLOW, B. L. (1999). I Like Being Who I Am: A Study of Young People's Ideals. Educational Studies, 25(2): 117-128.

ČÁP, J. (2010). Hledáme ideál českých dětí pro rok 2011. Instinkt, 50-51/10. Available at http://instinkt.tyden .cz/rubriky/ostatni/tema/hledame-ideal-ceskych-deti-pro-rok-2011_25771.html.

EWENS, W., LASHUK, M. (1989). Role model identification and activity preferences of Australian youth. Journal ACHPER National Journal, No. 125: 18-20.

FEMIAK, J., RYMARCZYK, P. (2010). Sport as a source of model personalities or idols? Between reality and medial illusion: sport as a source of model personalities or idols? Polish Journal of Sport and Tourism, 17(1): $1-6$.

PAYNE, W., REYNOLDS, M., BROWN, S., FLEMING, A. (2002). Sports Role Models and their Impact on Participation on Physical Activity. A Literature Review. VicHealth and University of Ballarath, Australia.

ROSI-MORI, B. (1998). The COMPASS Project - Coordinated Monitoring of Participation in Sports. Roma: CONI.

RYCHTECKÝ, A., DOVALIL, J., TILINGER, P. (2009). Vnímání olympijských her a olympijských principů mládeží a olympioniky ČR. Česká kinantropologie, 13 (3), 18-38.

SCHEEPERS, M. (2013). Selecting appropriate role models for our children. Sports Psychologist. Available at http://www.positivesportparent.com/.../selecting-appropriat (published April 5, 2013).

TELAMA, R., NAUL, R., NUPPONEN, H., RYCHTECKÝ, A., VUOLLE, P. (2002). Sportive Lifestyle, Motor Performance and Olympic Ideals: Cross-Cultural Studies on Youth Sport in Europe. Verlag Hofmann: ICSSPE, Sport Science Studies 11.

VESCIO, J., WILDE, K., CROSSWHITE, J. J. (2005). School of Leisure, Sport and Tourism, University of Technology, Sydney; Abbotsleigh High School, Sydney and Womensport and Recreation, NSW.

\section{JSOU OLYMPIONICI SKUTEČNÝMI IDOLY MLÁDEŽE V JEJÍ MOTIVACI A ÚČASTI VE SPORTU?}

\author{
ANTONÍN RYCHTECKÝ
}

\section{SOUHRN}

Cílem této studie bylo zjistit: „,zda olympijští vítězové jsou reálnými vzory a idoly pro dnešní mladé lidi“ a zdali by se chtěli, nebo nechtěli stát olympijskými vítězi, a s jakými důvody jsou asociovány jejich pozitivní či negativní odpovědí.

Respondenty a etapy výzkumů. V průzkumu, provedeném v letech 1998 bylo testováno 440 osob ve věku 12 a 15 let. Druhého šetření, v letech 2010-2011, se účastnilo 2364 jedinců, 1274 chlapců a 1090 dívek, ve věku 12 až 19 let dle principů kvótního výběru v Praze a Středočeském kraji, České republiky. Použit byl 
„Olympijský dotazník“ vytvořený a standardizovaný v prvním šetření z roku 1998. Otevřené, volné odpovědi respondentů byly následně rozděleny do několika obecných a společných kategorií.

Bylo předpokládáno, že touhu či přání stát se olympijským šampiónem pocitují intenzivněji respondenti z průzkumu provedeného v roce 1998 než v šetření realizovaném v období let 2010-2011. Mladí lidé, kteří se intenzivněji zapojují do sportu, vyjadřuji své přání stát se olympijskými vítězi výrazněji, než osoby méně či vůbec nesportující.

Testované osoby starší než 16 let si více uvědomují obtíže spojené s procesem stát se olympijskými vítězi než dospívající ve věku $12-14$ let.

K statistickému vyhodnocení rozdílů a shodných názorů mezi odpověd’mi respondentů ve sledovaných skupinách dle věku a pohlaví respondentů byly použity metody ANOVA, MANOVA a T-testy pro nezávislé vzorky.

Výsledky a závěry: hypotéza o významu sportovních vzorů a idolů současné mládeže byla potvrzena. Role olympijských šampionů jsou velmi důležité, zejména v internalizaci olympijských hodnot v procesu olympijské výchovy mládeže. Jak na školách, tak mimo školy. Olympionici by si měli být vědomi skutečnosti, že i jejich chování, které se př́mo netýká sportovních událostí, je objektem pozornosti mladých lidí. Olympionici by proto měli být informováni o jejich vlivu na mladou generaci. Masmédia mají velmi důležitou roli v jejich zprostředkování. Z těchto důvodů by měla být spolupráce mezi Klubem českých olympioniků a Olympijskou akademií inovována.

Klíčová slova: olympijská výchova, elitní sport, identifikace vzorů a idolů, touha stát se olympijským vítězem

Antonín Rychtecký rychtecky@ftvs.cuni.cz 